\title{
Scope of value addition to camel hide
}

\author{
Champak Bhakat* and M S Sahani \\ Camel Management Unit \\ National Research Centre on Camel, Bikaner -334 001, Rajasthan, India \\ * Correspondent author; E-mail : bhakat@scientist.com \\ Received 18 November 2004; Revised 4 April 2005
}

\begin{abstract}
Camel hides are utilized as natural product for preparation of a variety of consumer goods. In olden days it was popularly utilized for storing of ghee and oil under village condition. Hide of young calves are useful for making furs and those of adults are used for making leather. There is a great potentiality of utilization of camel hide as natural furs. The available trained persons engaged in rural cottage industry should be given proper incentives, training and facilities for promoting the utilization of camel hide. The paper deals with present status, future prospects and advantages of camel hide utilization.
\end{abstract}

Keywords : Camel, Natural product, Potentiality, Hide, Economics.

IPC code; Int. cl. ${ }^{7}$ — A41D 5/00, B68F 1/00, C14B 15/00

\section{Introduction}

Farmers of hot arid and semi arid desert region rely heavily on livestock enterprises for their sustenance. Camel rearing enterprise fits well with such requirements. The total world camel population is estimated to be 19.32 million of which India has 1.03 million (FAO, 2003). Indian camel population is mainly confined to North-western states, viz. Rajasthan, Gujarat, Haryana and Punjab with highest intensity of camel in arid districts of Rajasthan. The report on all India survey on raw hides has no references and statistical data regarding camel hides. This is mainly due to the infinitesimal population of camels in India as compared to other livestock species. Mostly Indian camels are managed in traditional extensive system and death of these camels occurs in field condition. So removal of skin is not possible in time which also leads to nonavailability of skin data.
Camel hides were largely utilized for storing of ghee and oil under village conditions about 4 to 5 decades back by Raikas/Rabaries and other camel rearing community. Presently camel hides are widely utilized for preparation of a variety of consumer goods (Stool cover, Purse, Bag, Jewellery Box, Toys, Mojari, etc.). It is also used for preparation of various decorative items (Ghara, Kuppi, Lampshade, etc.). Items of camel hide with gold carving made by Usta community are very popular as export potential item. In Egypt and the

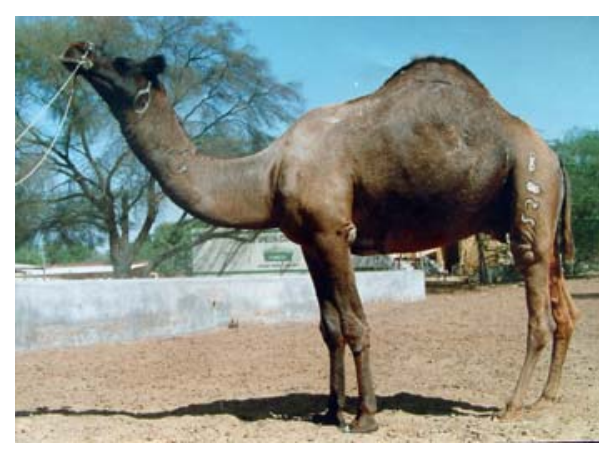

Indian camel at NRCC, Bikaner, India

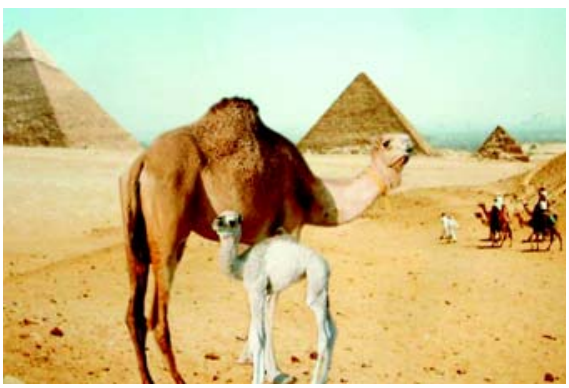

Egyptian camel in Giga Pyramids area of Egypt

Middle East camel hide is used for manufacturing utility items for tourists (Bhakat \& Sahani, 2000). Presently, camel hide appears to have little commercial use but if processed properly can be used for making leather goods, viz. shoes, sandels, etc. (Khanna, 2000). Camel hides can be used for making fancy items of tourist interest and it needs to be explored because very few people bother to take out the skin of a dead camel whereas this is not the case with the other livestock species. Wilson (1988) reported that the wet hides weighed between 22.5 and $47.0 \mathrm{~kg}$, equivalent to between 8.5 and 11.8 percent of empty live-weight. The possible areas and prospects of utilization of camel skin are discussed in the paper. Possibilities of exploring for modern use with the help of newer technology, in addition to the traditional uses, structure of camel skin, advantage of camel hide and various steps for processing of camel hide have also been discussed in this paper. 


\section{Structure of camel skin}

Anatomical studies of camel skin are few in numbers. The skin of camel is unique among domestic animals. The epidermis of camel usually consists of following layers (Murray, 1998):

(i) Stratum corneum (horny layer) represents $1 / 2-3 / 4$ of the total epidermal thickness. This layer consists of fully keratinized cells pushed up from basal layers; (ii) Stratum lucidum is occasionally seen in sparsely haired skin as a dense eosinophilic layer beneath the stratum corneum; (iii) Stratum granulosum (granular layer) is a single layer of cells in some areas and discontinuous in others. The nuclei are pycnotic, and most of the cytoplasm has been replaced with keratin; (iv) Stratum spinosum (prickle layer) is reduced but is composed of daughter cells of the basal layer and is 1-3 cells thick. These cells are viable and nucleated and actively synthesize keratin; (v) Stratum germinativum is the deepest layer of the epidermis and consists of a single layer of cuboidal or columnar cells, most of which are keratinocytes with a few

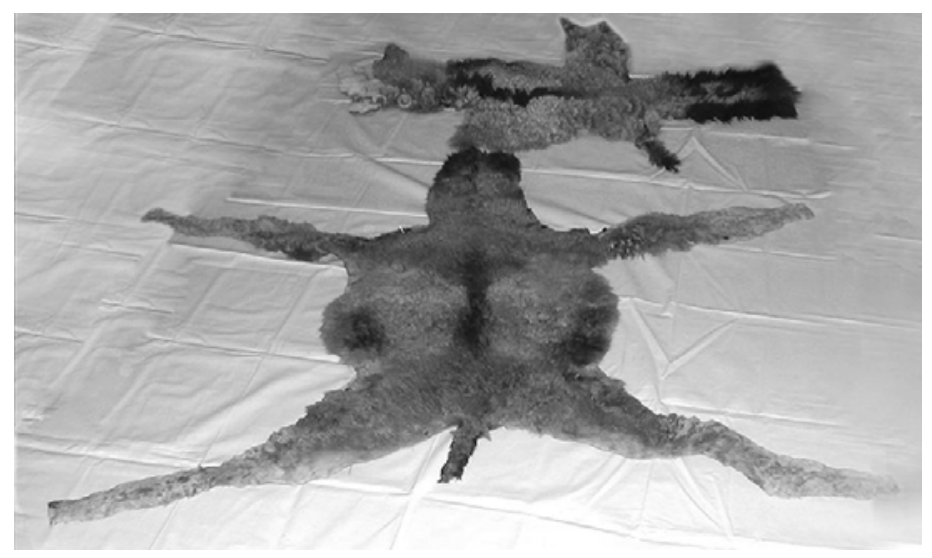

Furs of the skin of camel calves melanocytes. Melanocytes contain melanin pigment in pseudopods distributed between epidermal cells of the skin and hair. Skin colour is determined by the number, size, arrangement and dispersion of melanin granules (Goswami et al, 1994). The dermis (corium) is thick (up to $1 \mathrm{~cm}$ in the cervical region of a mature male camel) and consists of a superficial layer composed of loose connective tissue interdigitating with undulations in the epidermis and the deep dermis, which is composed of dense fibrous tissue. The dermis contains hair follicles, blood and lymph vessels, nerves, and sebaceous and sweat glands. The middermis is characterized by a proliferation of blood vessels, in contrast to that in other domestic animals. Vessel walls are hyalinized. There is variation in the thickness of the epidermal layers in various areas of the body. Also, the degree of vascularity and mononuclear infiltration may vary. The hypodermis (subcutis) is composed of loose connective tissue, which attaches skin to the underlying bones or muscles. Some sweat glands extend into the hypodermis.

Advantage of camel hide

$\mathrm{C}$ a m e 1 hides, if tanned and converted into leather or furs have following advantages: (i) it has good 'substance' which means thickness, t o u g h n e s , compactness and texture of the hide are of good quality; (ii) camel skin is versatile in use, which means that skin of young calves are useful for making furs and those of adults are used for making leather; and (iii) the unique translucent structure of camel hides makes them especially useful for making the articles such as lampshades, toys, drum leather and containers of various types.

\section{Processing of camel hide for natural products}

The raw camel hides are obtained from few areas only in small number from "fallen" stock, which have been allowed to linger on till they die of old age or disease or by accident, since in India camels are not slaughtered for meat or any other purpose. Flaying of camel hides is generally done manually by the people engaged in the business of collection of raw hides. The flaying of camel hide is not an easy job due to its large body size. Flay cuts and scores are, therefore, a common sight on flayed hides. The raw hides are mostly 'cured' (preserved) by air-drying or drying in direct sunlight. As the semi-dried hide possess many problems during later stages of processing. It is necessary that the people engaged in this business are made conversant with the method of curing by applying dry common salt.

\section{Processing of camel calf skin}

The skins of young camel calves can provide the best raw material for making good quality furs as it hold 
lustrous, fine and soft hair covering of excellent quality and silky feeling in nature. The hair is naturally coloured in varying shades and tones ranging from light fawn to dark brown colour. The semidried camel calf skins have to pass through following chemical and mechanical treatments before they get actually converted into a fur. Adequate precautionary measures are to be taken to preserve the original characters of hair, viz. colour, luster, silkiness, etc. and also to impart other properties of a fur such as flexibility, elasticity, softness, suppleness, etc.

Soaking — Soaking raw camel calf skins in water is the first treatment. This rehydration process uses the common salt, some wetting agent and a bactericide invariably as additives to the soak-bath to dissolve the proteins such as albunins, globulins, mucins and mucoids, etc. and to avoid bacterial attack.

Removal of flesh — Soaking followed by removal of flesh, the adipose tissue which is not part of hide but a loose connective layer lying between the true skin (Corium) and actual body muscles of the camel. This is done by scrapping with blunt knives.

Pickling — The skins are then treated with a mixture of acid and common salt in order to open up the texture of collagen fibres and to condition them for tanning which facilitates better penetration of tanning chemical towards production of soft and flexible skins.

Tanning — The process which converts the raw skin into leather is called tanning. The formaldehyde tanning followed by combination tannage of "alum + chrome" gives best results in terms of strength, flexibility, pliability and softness of the end-product in comparison to either chrome tannage or alum tannage along (Patani \& Dhillon, 1988).

Fat liquoring — The tanned skins are 'oiled' or 'fatliquored' by applying emulsion of oil or fat on the flesh side of the skin. The dried fat liquored skins are then conditioned in moist raw dust followed by mechanical operations such as dusting, staking and buffing, etc.

Washing — It is then finally washed and dried.

\section{Processing of adult camel skin}

The hides of adult camels have excellent properties of leather making. The leather making process is comparatively more complex and lengthy procedure than fur making. It involves a larger number of operations, many labours and huge machinery. The additional operations in making leather are treatments of cured camel hides with lime and sodiumsulphide (liming process) for dehairing, removal of final traces of lime treatment with certain enzymes (bating process), dyeing, resin finishing and/or lacquer finishing. The resin finishing consists of treatments of applying staining coat, seasoning coat by using some resin bindery hot plating (ironing) and glaze finish. In order to add water-repellent properties to the finished leather, it is subjected to lacquer finishing also (Bhakat \& Sahani, 2003).

\section{Future scope and potentiality}

There is a great potentiality of utilization of camel skin as furs, keeping in view the excellent fur making properties of camel calf skins. The camel furs with their inherent natural colour, luster and softness are most suitable for wall hangings, fur garments and furniture coverings, etc. The superior leather making quality of adult camel hides are useful for a wide range of articles, viz. mojari, handbags, saddlery harness, etc. and several other items. Camel hides also serve as an important base material for many valuable decorative objects. The objects such as lamp shades, containers of various types, shapes and sizes, show pieces and similar other decorative articles are made of dried untanned camel hides and their surfaces are painted in gold. The golden paintings on these articles have fascinated the people of the world over. This craft has touched the heights of its perfection in the city of Bikaner itself. The foreigners who traveled from every corner of the world and happen to visit the desert region are attracted and tempted to buy these articles even at extortionate prices. In the olden days the camel hide containers had their use for transporting ghee, oils, scents, perfumes and other such commodities. With the rise of civilization and advancement of much better substitutes later on, it became antiquity and decorative and some useful items.

The raw camel hides to be used for making such articles are soaked in water without any bactericide being added to it and allow partial and controlled bacterial attack. As it starts smelling bad the bacterial action is partly controlled by adding ammonium chloride. In order to facilitate the easy removal of epidermis layer, a little quantity of sodium sulphide is also added. The process takes 2 to 3 days, when the hides become plumpy and dehaired. Then flesh (adipose layer) is also scrapped. 


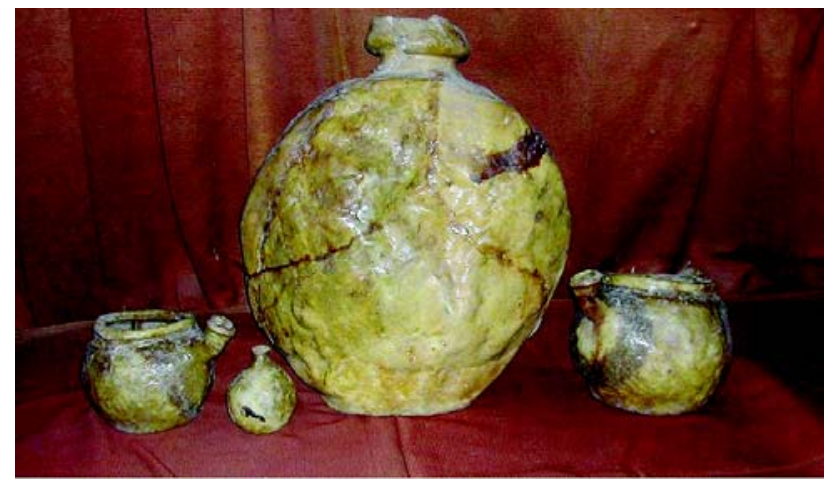

Ghara and kuppi of camel hide used in olden days 'pasted' on joints with a paste in water of finely ground 'Methi grains'. After complete drying, the object is gently beaten so that clay is removed. This object is now ready for golden painting work over it. The craft of painting may take 2 to 3 months for completion depending upon shape, design and size of the object. It is claimed that the painting, being of pure gold is unaffected by all w e a $t h$ e $r$ conditions and does not get $\mathrm{d}$ a $\mathrm{m}$ a g e d, discoloured in many decades. The cost of small

This wet (semi-dry) and pliable hide is wrapped over the 'die' which is nothing but a model of clay having shape and size of the final product. The hide is

article varies from Rs. 500/- to Rs. 3,000/ - whereas the cost of big item varies from Rs. 10,000/- to Rs. 12,000/-.

\section{Conclusion}

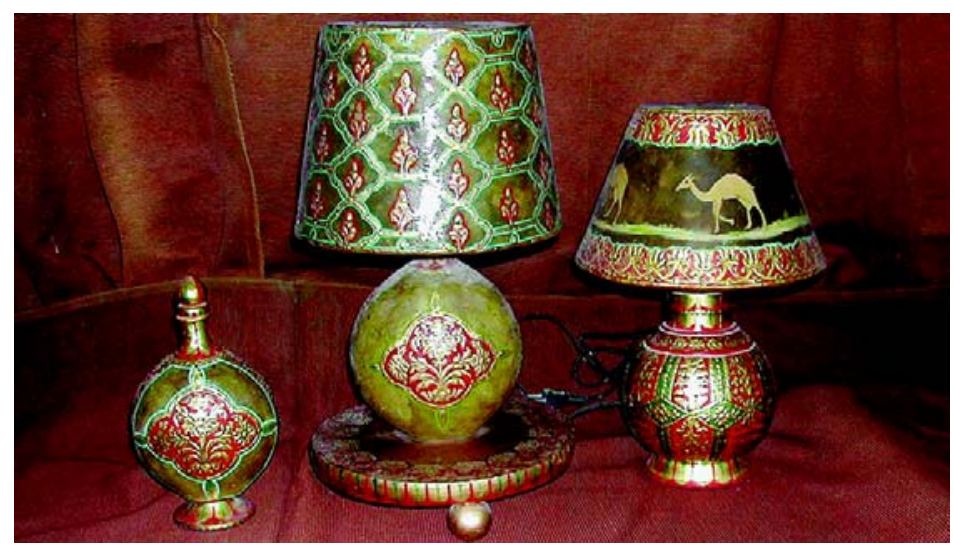

Decorative lamp shades and kuppi of camel hide with gold paints
Looking to the wide utility and export potentiality of camel hide as natural product, it can be used for $\mathrm{v}$ a $\mathrm{r}$ i 0 u $\mathrm{s}$ purposes. The available trained persons engaged in rural cottage industry may be given proper incentives, training and facilities for promoting the utilization of camel hide. The utility items made up of camel hide are good source of income for farmers in hot arid and semi-arid region of desert ecosystem.

\section{References}

1. Bhakat $\mathrm{C}$ and Sahani MS, A comprehensive study of the camel production system in the North West Coastal Zone of Egypt, Livestock Int, 2000, 4(10), 4-7.

2. Bhakat $\mathrm{C}$ and Sahani MS, Scope and utilization status of camel skin. Paper presented at National Seminar on Leather Industry in Today's perspective at Kolkata, 14-15 ${ }^{\text {th }}$ Nov-2003, pp- 73-76.

3. FAO production yearbook, Rome, Italy, 2002.

4. Goswami SK, Dhingra LD and Nagpal SK, Regional differences in the pigmentation of skin in camel, Indian J Anim Sci, 1994, 64 (4), 328-330.

5. Khanna ND, Camel production in India's livestock sector, In: Arid Ecology: Resources, Hazards and Rural Development Policies/ edited by SC Kalwar, MK Khandelwal and BL Gupta. 1999, 2 Volumes, 543 p; Vol. II: Agriculture and Irrigation Projects, 2000, pp. 508-509.

6. Murray E Fowller, Medicine and surgery of south American Camelids Chapter on Integumentary system, 1998, pp. 250-251.

7. Patani PC and Dhillon RS, Areas and prospects of utilization of camel hair and hide. National Seminar on Perceptions and Potential of Camel Research in India, NRCC, Bikaner, 1-11, 1988.

8. Wilson RT, The Camel. Chapter on Productivity, 1988, pp. 161-172. 